\title{
The Effect of Crop Load on Tree Water Consumption of 'Golden Delicious' Apples in Relation to Fruit Size: An Operative Model
}

\author{
Shaul Naschitz and Amos Naor ${ }^{1}$ \\ The Golan Research Institute, P.O. Box 97, Kazrin 12900 Israel
}

ADDITIONAL INDEX WORDS. irrigation, fruit size, fruit diameter, maintenance respiration, water use efficiency, Malus $\times$ domestica

\begin{abstract}
Water availability and crop load (number of fruit per tree) affect the fruit size of apple (Malus $\times$ domestica Borkh.), but their interaction in relation to fruit size is not well understood. The objective of the present study was to explore the effect of crop load on water consumption of 'Golden Delicious' apple in relation to fruit size. A wide range of irrigation rates and crop loads was applied to mature, field-grown 'Golden Delicious' apple trees for two consecutive years, 1995 and 1996. The number of fruit, crop yield, and average fruit diameter were determined for each tree. A model was proposed to describe the combined effect of crop yield and irrigation rate on fruit size. In the model, irrigation waters were divided between two uses: vegetative water use $\left(U_{v}\right)$, which enables the tree to produce a steady, long-term yield; and reproductive water use $\left(U_{R}\right)$, which supports the production of the dry mass of commercial-size fruit. Potential fruit diameters were 77.1 and $72.2 \mathrm{~mm}$ for 1995 and 1996 , respectively. Calculated vegetative use values were 300.2 and $323.4 \mathrm{~mm}$ for 1995 and 1996, respectively. The response of fruit diameter to reproductive water use per ton fresh weight (specific reproductive water use; $U_{\mathrm{RT}}$ ) was fitted by a hyperbolic model in which the fruit diameter increases with increasing specific reproductive water use and approaches the yearly potential diameter at 60 to $^{2} \mathrm{~m}^{3} \cdot \mathrm{t}^{-1}$, irrespective of the potential fruit diameter. In both years, fruit diameter showed a closer correlation with the specific reproductive water use than with either crop load or irrigation rate. In conclusion, the crop yield and the potential fruit size determine the irrigation rate required to achieve a certain average fruit diameter. The year's potential fruit diameter does not affect the total tree water use or its components. The proposed model can be used by growers for supporting decisions on irrigation and thinning strategies in commercial orchards.
\end{abstract}

Fruit size is a major aspect of apple quality. Since fruit size is affected by water deficit, and since water is a limiting factor to fruit production in some apple-producing regions, both economically and physically, optimizing water application is increasingly important.

Fruit size is negatively related to crop load (number of fruit/ tree) in apple (Assaf et al., 1982; Erf and Proctor, 1987; Naor et al., 1997a, 1997b) and in other deciduous fruit trees (DeJong and Grossman, 1995; Naor et al., 1999, 2000, 2004). Limited availability of assimilates has been suggested as the reason for obtaining smaller fruit at high crop loads in peach (Prunus persica L.; DeJong and Grossman, 1995) and in apple (Wibbe et al., 1993). The number of cells in the pericarp may limit potential apple fruit size, and this number depends on the temperature during the cell-division phase (Austin et al., 1998; Bergh, 1990; Flaishman and Naor, unpublished; Warrington et al., 1999). Fruit size also depends on crop loads in the current and the previous seasons (Bergh, 1985).

Apple yield and fruit-size distribution are affected by the irrigation rate (Assaf et al., 1982; Erf and Proctor, 1987; Naor et al., 1997a); fruit was smaller for a high crop load than for a lower crop load when subjected to "deficit irrigation" (Mpelasoka et al., 2001). Stomatal conductance increases (Erf and Proctor, 1987; Hansen, 1971) and midday stem water potential decreases (Naor et al., 1997b) as the crop load of stressed apples increases. These responses provide us with qualitative indications of the effect of crop load on tree water consumption. Compared with nonfruiting

Receieved for publication 8 Feb. 2004. Accepted for publication 20 May 2004 .

1To whom reprint requests should be addressed; e-mail: amosnaor@research. haifa.ac.i apple trees, fruiting trees had higher water consumption in containerized (Lenz, 1986) and lysimeter-grown trees (Mpelasoka et al., 2001). Lenz (1986) directly demonstrated that the tree water consumption of fruiting trees was $25 \%$ to $50 \%$ greater than that of nonfruiting ones in a controlled environment. Nevertheless, there is a lack of quantitative information on the effect of crop load on tree water consumption in field-grown apple.

Optimal irrigation is expected to maintain a well-balanced tree structure (roots, limbs, shoots, leaves, and flower buds) that can provide the fruit with enough assimilates at an adequate rate for them to reach commercial fruit size, and to ensure enough fertile-flower bud formation to enable steady commercial crop yield production. A balanced tree structure can be achieved provided vegetative growth is adequate for the formation of a sufficient number of flower buds and for the postharvest accumulation of assimilates in the tree-carbohydrate pool. The fulfillment of both these conditions would enable persistent cropping. Ebel (1991) showed that apple trees grown in a semiarid zone could survive one unirrigated season, provided that there was adequate moisture storage in the soil profile. Nevertheless, the canopy size of the unirrigated trees decreased to $40 \%$ in the subsequent year, and the number of fruit/tree was reduced to $55 \%$ of the number on the well-irrigated trees. This demonstrates that the tree water consumption required to maintain a well-balanced tree structure is considerably greater than the survival water consumption. There is a need to quantitatively evaluate the amount of irrigation required to maintain a well-balanced tree structure, and the additional water consumption necessitated by the presence of a crop.

The objective of the present study was to establish a model for describing the combined effect of crop yield and irrigation rate on the fruit size of field-grown 'Golden Delicious' apple. 


\section{Materials and Methods}

Model DESCRIPTION. It is assumed that the response of crop yield to soil moisture availability at a given crop load (number of flowering buds) has a single sigmoidal pattern (Fig. 1). There is a minimum soil moisture availability (A) below which trees might dry out and die; A-B represents a section where the proportion of fruit set and the proportion of surviving fruitlets increase with increasing water use (Powell, 1974) as a result of either improved turgor potential or of improved assimilate availability to the fruit that may prevent fruit drop. When water use is in the A-B range, a reduction in the structure dry biomass may occur, mainly by defoliation and by a negative balance in root turnover (Ebel, 1991; Lakso et al., 1999; Lenz, 1986). Nevertheless, trees will survive; B-C represents a section where both assimilate availability for fruit expansive growth and potential fruit size limit crop yield. When water availability is in the $\mathrm{B}-\mathrm{C}$ section, trees may retain their structure. Shoot growth would increase with increasing water use to retain cropping potential until a certain point (undefined) from which additional water use might induce excessive shading within the canopy. Tree water use in commercial orchards is usually in section B-C, and reduced crop load in field-grown apple was reported only under nonirrigation (Ebel, 1991) or deficit irrigation in the cell division phase (Naor et al., unpublished; Powell, 1974). Therefore, the following analysis is restricted to high water use values (B-C) (Fig. 1) where both assimilate availability and potential fruit size limit crop yield and fruit size.

In the following model, irrigation water is divided into two components. The first is the water use for vegetative growth in addition to available soil moisture at budbreak $\left(\mathrm{U}_{\mathrm{v}}\right)$, which is the water use below which fruit drop would significantly limit crop yield. The second component is the reproductive water use $\left(\mathrm{U}_{\mathrm{R}}\right)$, which represents the water use designated to support the production of the dry mass of commercial-size fruit.

The degree to which the potential fruit size is achieved depends on the specific reproductive water use (reproductive water use per 1 metric ton of fruit; $\mathrm{U}_{\mathrm{RT}}$ ), which affects the ability of the canopy to supply the crop with assimilates at an adequate rate (DeJong and Grossman, 1995).

$$
\mathrm{U}_{\mathrm{RT}}=\frac{\left(\mathrm{I}_{\mathrm{tot}}-\mathrm{U}_{\mathrm{V}}\right)}{\mathrm{Y}_{\mathrm{tot}}}
$$

where $\mathrm{U}_{\mathrm{RT}}=$ irrigation per ton of fruit $\left(\mathrm{m}^{3} \cdot \mathrm{t}^{-1}\right) ; \mathrm{I}_{\mathrm{tot}}=$ total annual irrigation $\left(\mathrm{m}^{3} \cdot \mathrm{ha}^{-1}\right) ; \mathrm{U}_{\mathrm{V}}=$ annual amount of water designated for vegetative growth in addition to the available soil moisture at budbreak $\left(\mathrm{m}^{3} \cdot \mathrm{ha}^{-1}\right)$; and $\mathrm{Y}_{\text {tot }}=$ total crop yield $\left(\mathrm{t} \cdot \mathrm{ha}^{-1}\right)$.

In an "efficient" apple orchard the irrigation efficiency is assumed to be $100 \%$, and the availability of assimilates is not a limiting factor; i.e., the crop load is in the range where the yield response to crop load is linear (DeJong and Grossman, 1995) (Fig. 2). The response of fruit diameter to the specific reproductive water use in an "efficient" apple orchard follows a hyperbolic curve:

$$
\mathrm{D}=\frac{\mathrm{D}_{\max }\left(\mathrm{I}_{\mathrm{tot}}-\mathrm{U}_{\mathrm{V}}\right) \mathrm{Y}_{\mathrm{tot}}^{-1}}{\left(\mathrm{I}_{\mathrm{tot}}-\mathrm{U}_{\mathrm{V}}\right) \mathrm{Y}_{\mathrm{tot}}^{-1}+\mathrm{b}}
$$

where $\mathrm{D}, \mathrm{D}_{\max }=$ fruit diameter, potential fruit diameter $(\mathrm{mm})$; and $\mathrm{b}=$ slope constant.

FEasibILITY TEST. Data from an old irrigation experiment were used for the feasibility test. The experimental settings have been reported in detail elsewhere (Naor et al., 1997a, 1997b). The experimental plot consisted of a 12-year-old drip-irrigated commercial orchard of 'Golden Delicious' apple on 'Malling-Merton

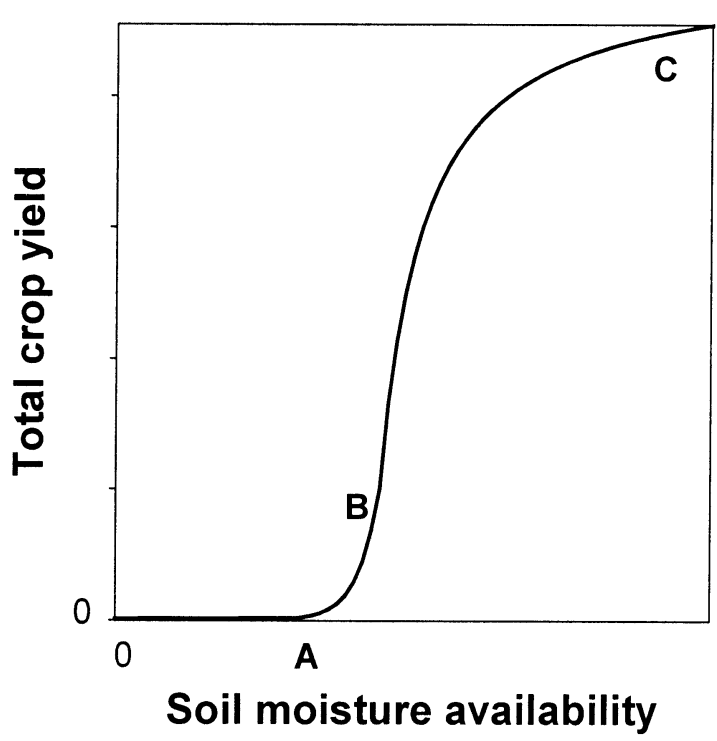

Fig. 1.A schematic representation of the relation between soil moisture availability and crop yield.

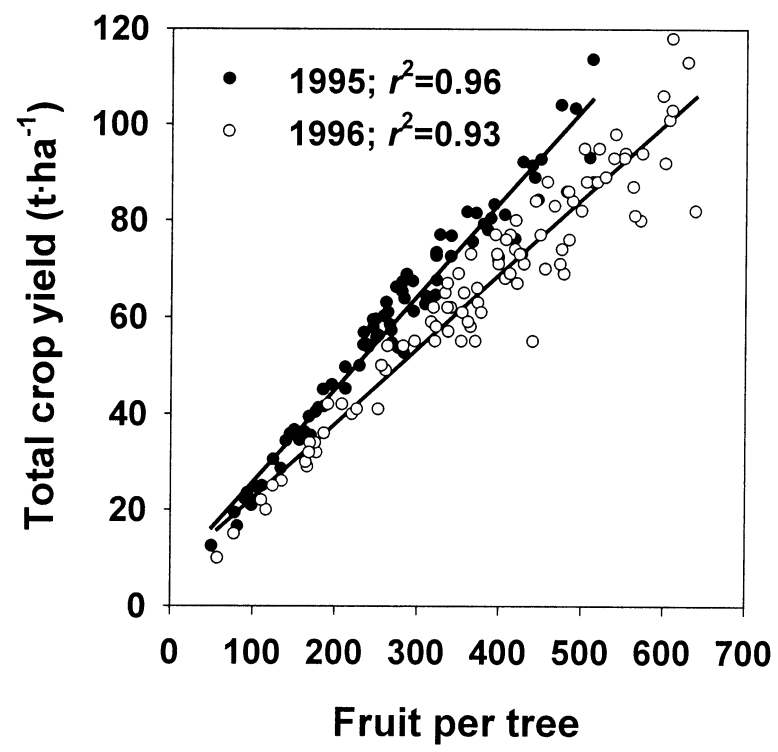

Fig. 2. The effect of crop load (fruit/tree) at five irrigation rates on the total yield $\left(\mathrm{t} \cdot \mathrm{ha}^{-1}\right)$ in $1995(\mathrm{n}=79)$ and in $1996(\mathrm{n}=92)$.

106 ' rootstock spaced at $4 \mathrm{~m}$ between rows $\times 2 \mathrm{~m}$ within row. The trees formed a full hedgerow, about $3 \mathrm{~m}$ in height with a relatively uniform canopy structure. The experimental plot was irrigated until mid-June according to commercial practice: irrigation started about 1 May at a Class A pan evaporation coefficient of 0.30 and was systematically increased, in coordination with the increase in canopy size and in fruit diameter, to reach 0.45 in mid-June. Differential irrigation treatments were started in mid-June, at the beginning of the main cell expansion phase in the fruit mesocarp. An additional $90 \mathrm{~mm}$ of water was applied to all treatments over 6 weeks from the end of harvest until the beginning of the rainy season in late October. The experimental design enabled the study of the interaction of irrigation and crop load during the main period of fruit growth. The experimental design was a split-plot factorial, with five irrigation rates as main plots and 
crop loads as subplots. The treatments were replicated five times in a complete randomized block design. Each main plot consisted of four adjacent rows of four trees, and only the four inner trees of each plot were used for the four crop load treatments. The irrigation rates applied were Class A pan evaporation coefficients of $0.42,0.58,0.75,0.90$, and 1.06 in 1995, and 0.42, 0.58, 0.71, 0.87 , and 1.03 in 1996 . The fruit on each tree were counted at the beginning of June and were hand-thinned to four crop load levels: 0 to 150,151 to 250,251 to 350 , and $>350$ fruit/tree. After harvest the fruit of each tree were weighed, and the diameter distribution was determined by means of a commercial grading machine (55 to $75 \mathrm{~mm}$ ). The experiment was repeated with the same trees for two consecutive seasons, 1995 and 1996. Crop loads were switched between trees where necessary.

Statistical analysis. Average fruit diameter, total crop yield for each tree, and total annual irrigation rates were used to evaluate the parameters of the model (Eq. 2) by means of nonlinear regression analysis (Sigmaplot, V 7.0; SPSS Inc., Chicago).

\section{Results}

The annual irrigation rates were 446, 536, 632, 723, and 817 $\mathrm{mm}$ in 1995 , and $422,524,600,702$, and $804 \mathrm{~mm}$ in 1996 . The crop loads ranged from 50 to 510 fruit/tree in 1995 and from 55 to 640 fruit/tree in 1996. Yields were linearly related to crop loads (Fig. 2) and ranged from 12 to 114 t.hat $\mathrm{a}^{-1}$ in 1995 and from 10 to $118 \mathrm{t}^{\cdot \mathrm{ha}^{-1}}$ in 1996. Crop yields were higher in 1995 than in 1996 for each crop load (Fig. 2). The wide ranges of irrigation rates and crop loads allowed the investigation of wide ranges of specific reproductive use (Eq. 1): from 6 to $320 \mathrm{~m}^{3} \cdot \mathrm{t}^{-1}$ in 1995 and from 4 to $240 \mathrm{~m}^{3} \cdot \mathrm{t}^{-1}$ in 1996 (data not shown). Potential fruit diameters differed between years and were 77.1 and 72.2 $\mathrm{mm}$ in 1995 and 1996, respectively (Table 1; Fig. 3) Vegetative water use values were 300.2 and $323.4 \mathrm{~mm}$ for 1995 and 1996, respectively (Table 1). The relative fruit diameter (average diameter expressed as a fraction of the year's potential fruit diameter) responded similarly to specific reproductive water use in both years, increasing with specific reproductive use and approaching 1 at 60 to $70 \mathrm{~m}^{3} \cdot \mathrm{t}^{-1}$ (Fig. 4).

Fruit diameter was better correlated with crop load (number fruit/tree) than with annual irrigation rate in 1995 (Table 2) whereas the opposite was apparent in 1996. In both years fruit diameter had the highest correlation with specific reproductive use, a parameter that takes into account the effects of both the irrigation rate and the crop yield.

Asimulation based on the combined data of 1995 and 1996 (Fig. 4; Table 1) shows that the reduction in fruit diameter in response to crop yield becomes more pronounced with decreasing annual irrigation rate (Fig. 5). A reduction of annual irrigation rate from 1000 to $700 \mathrm{~mm}$ would result in a decrease in fruit diameter of

Table 1. The parameters of the model (Eq. 2) for 1995, 1996, and for the merged data with fruit diameter relative to its maximum value each year. The parameters were significant at $\alpha<0.0001$.

\begin{tabular}{|c|c|c|c|}
\hline & 1995 & 1996 & $1995+1996$ \\
\hline $\begin{array}{l}\text { Potential fruit diam } \\
\qquad(\mathrm{mm}) \pm \mathrm{SE}\end{array}$ & $77.1 \pm 0.42$ & $72.2 \pm 0.55$ & $100 \% \pm 0.47$ \\
\hline $\begin{array}{l}\text { Vegetative water use } \\
\qquad(\mathrm{mm}) \pm \mathrm{SE}\end{array}$ & $300.2 \pm 39.8$ & $323.4 \pm 30.2$ & $320.5 \pm 22.4$ \\
\hline$r^{2}$ & 0.58 & 0.56 & 0.58 \\
\hline $\mathrm{n}$ & 79 & 92 & 171 \\
\hline
\end{tabular}

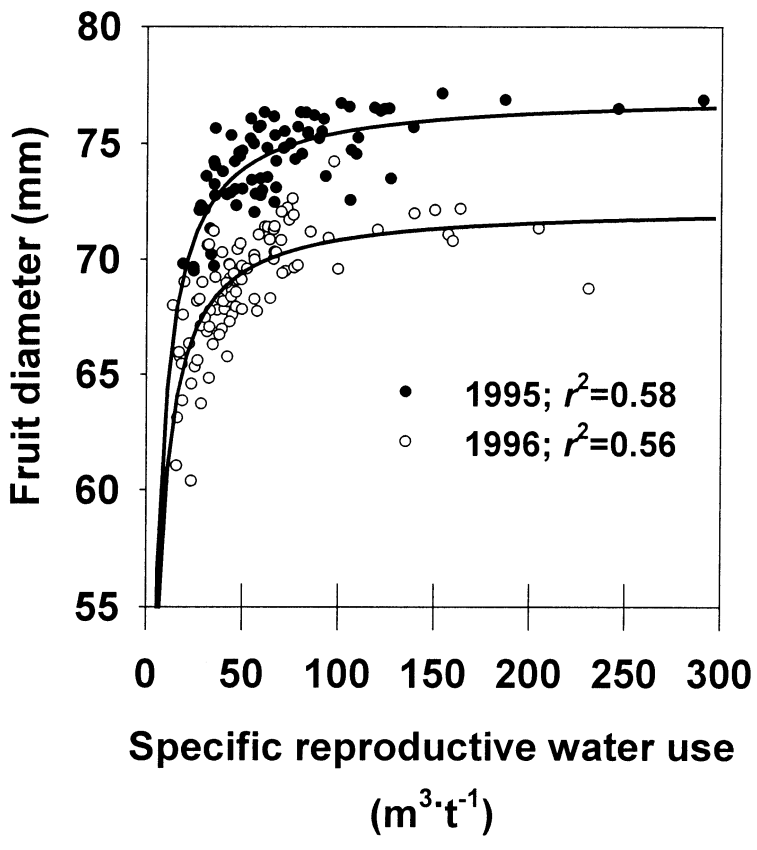

Fig. 3. The effect of irrigation rate per ton of fresh weight (specific reproductive water use; $\mathrm{m}^{3} \cdot \mathrm{t}^{-1}$; Eq. 1) on fruit diameter in $1995(\mathrm{n}=79)$ and in $1996(\mathrm{n}=$ 92).

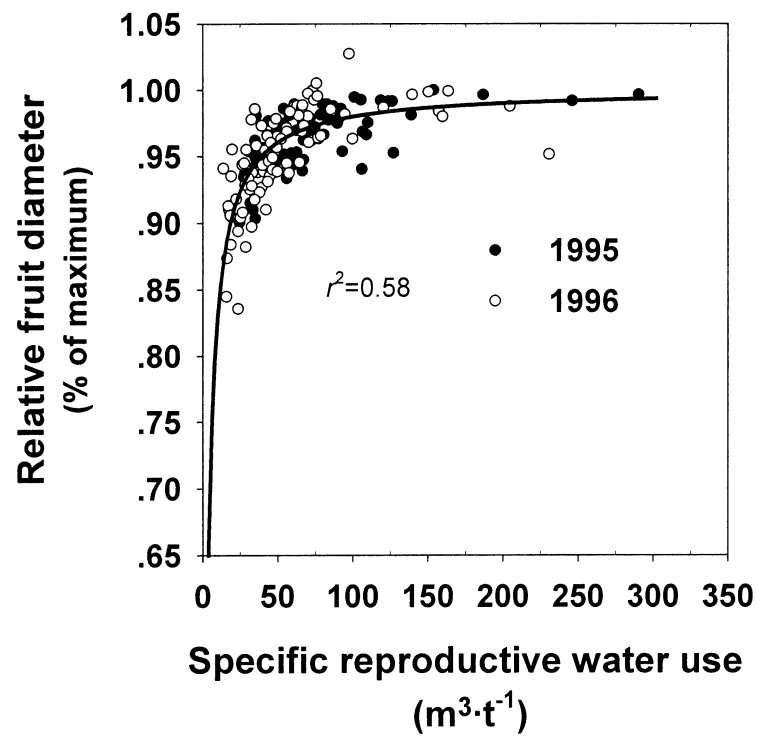

Fig. 4. The effect of irrigation rate per ton of fresh weight (specific reproductive water use $\mathrm{m}^{3 \cdot} \cdot \mathrm{t}^{-1} ; \mathrm{Eq} .1$ ) on relative fruit diameter (average diameter expressed as a fraction of the year's potential fruit diameter) in $1995(\mathrm{n}=79)$ and in $1996(n=92)$.

Table 2. Correlation coefficients $\left(r^{2}\right)$ between fruit diameter at harvest and total irrigation, number of fruit/tree, and specific reproductive water use (Eq. 1).

\begin{tabular}{lcc} 
& 1995 & 1996 \\
\hline Total annual irrigation & 0.262 & 0.431 \\
Crop load (fruit/tree) & 0.354 & 0.268 \\
Specific reproductive water use & 0.539 & 0.570 \\
$\mathrm{n}$ & 79 & 92 \\
\hline
\end{tabular}




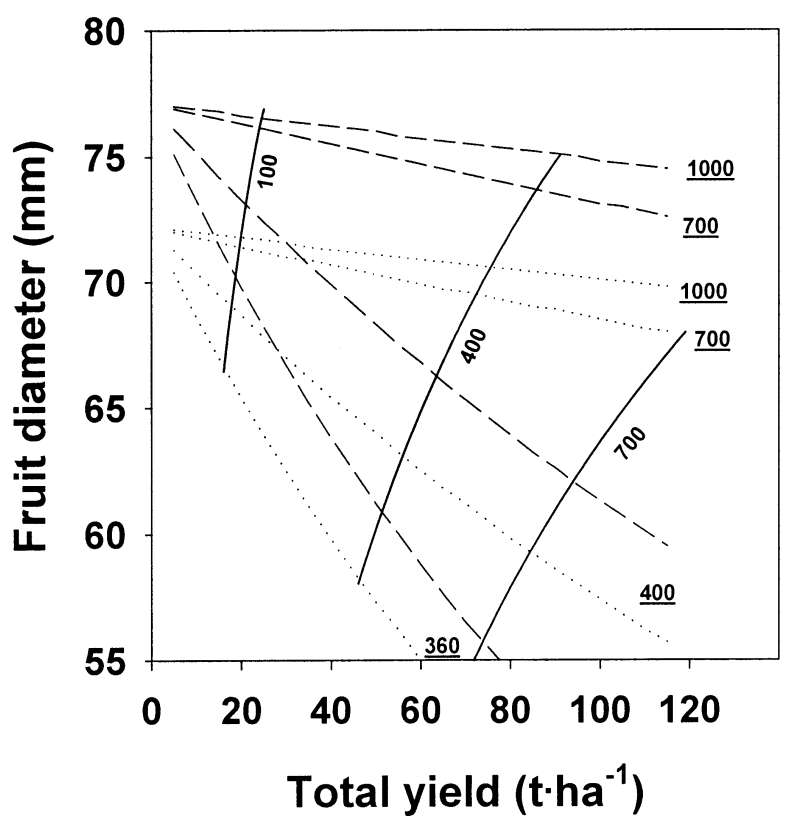

Fig. 5. A simulation of the effect of crop yield on fruit diameter at various annual irrigation rates in 1995 (dashed lines) and 1996 (dotted lines) and the effect of crop yield on fruit diameter at 100,400, and 700 fruit/tree (solid line). Underlined numbers are annual irrigation rates $(\mathrm{mm})$. The simulation was restricted to irrigation rates and crop loads within the actual experimental ranges.

0 to $2 \mathrm{~mm}$, while a reduction of irrigation rate from 700 to 400 $\mathrm{mm}$ would result in a dramatic decline in fruit diameter, namely $7 \mathrm{~mm}$ at 400 fruit/tree and $10 \mathrm{~mm}$ at 700 fruit/tree. The effects of crop yield on fruit diameter at three crop loads, 100, 400, and 700 fruit/tree, are presented in solid lines (Fig. 5). Differences in fruit diameter between years are large at low crop yield and high annual irrigation rate, whereas they decrease at high crop yield and low annual irrigation rate.

\section{Discussion}

In the present study, higher crop yields were apparent for every crop load in 1995 than in 1996, indicating a larger potential fruit size in 1995. The fulfillment of the differences in potential fruit size occurred at high irrigation rates and low crop yields (Fig. 5) when availability of assimilates did not limit fruit growth. On the other hand, at low irrigation rates and high crop yields, where assimilate availability limits fruit expansive growth, the difference in fruit size between years decreased.

The cost in terms of water use for the production of $1 \mathrm{t}$ (fresh weight) of apple fruit was estimated as follows. A typical water use efficiency ratio of C3 plants on a mass basis is $1: 205$ (Taiz and Zeiger, 1991); typical dry matter content for 'Golden Delicious' apple fruit is $16 \%$ (Lakso et al., 1999). There would be an additional small cost to account for maintenance and growth respiration of the fruit (Proctor et al., 1976) as well as a more substantial metabolic cost for processes involved in translocation of assimilates from the leaves into the fruit (Wibbe et al., 1993). On the assumption of a respiratory cost equivalent to $30 \%$ of the total carbon fixed by the canopy (Walton and Fowke, 1995), the overall cost in terms of water consumption for the production of $1 \mathrm{t}$ (fresh weight) of apples would be $\sim 47 \mathrm{~m}^{3}$. It should be noted that this value is only a rough estimate and may change from one region to another because of climatic differences, which affect both respiration and water use efficiency on a leaf basis $\left(\mathrm{WUE}_{\text {leaf }}\right)$.

Applying specific reproductive water use amounts lower than $47 \mathrm{~m}^{3} \cdot \mathrm{t}^{-1}$ might cause a shift in assimilate translocation in favor of the fruit, which would harm tree structure in the long term, because of attenuation of shoot growth (Ebel, 1991). Applying specific reproductive use levels higher than $47 \mathrm{~m}^{3} \cdot \mathrm{t}^{-1}$ would increase the proportion of assimilates transported to the tree structure, which could be manifested in excessive shoot growth. Consistent application of specific reproductive use levels either higher or lower than $47 \mathrm{~m}^{3} \cdot \mathrm{t}^{-1}$ for a few years is expected to result in the adjustment of the tree structure so as to change vegetative water use until the actual specific reproductive use approaches $47 \mathrm{~m}^{3} \cdot \mathrm{t}^{-1}$ in a new steady-state condition. The similar response of fruit diameter to specific reproductive use in both years (Fig. 5) suggests that the damage to the structure in 1995 at specific reproductive use lower than $47 \mathrm{~m}^{3} \cdot \mathrm{t}^{-1}$ was nonsignificant over a 2-year period.

The vegetative water use depends on the demand for maintenance respiration of the leaves, roots, and stem (Grossman and DeJong, 1994), and on the evaporative demand, which determines transpiration rates throughout the growing season. Since respiration exhibits an exponential response to temperature (Grossman and DeJong, 1995; Proctor et al., 1976), weather conditions during fruit growth may have an impact both on dark respiration and on net photosynthesis during the day, so that the weather is a major factor in determining the water consumption of orchards. Vegetative use is positively related to the canopy biomass per unit area of orchard (i.e., hedgerow height) as it dictates the amount of light intercepted by the canopy (Lakso et al., 1999) and the total maintenance respiration of the tree (Grossman and DeJong, 1994). Canopy size affects the yield capacity of the tree and the crop yield at which assimilate availability becomes a limiting factor; therefore, a high vegetative use does not necessarily imply that the trees are inefficient.

The low response of fruit diameter at high specific reproductive water use levels (Fig. 4) demonstrates a carbon partitioning pattern that favors fruit over nonreproductive tissue, which is consistent with previous findings (e.g., DeJong and Grossman, 1995). Therefore, if the irrigation supply falls short of meeting the added water requirements of the canopy and of the crop, it will necessarily result both in a smaller crop yield in the current year through a reduction in fruit size, and in inhibited canopy growth, which might be accompanied by a decrease in the reserves of assimilate stored in the stem (Lakso et al., 1999) and thus limit canopy development and fruit set early in the following year (Ebel, 1991; Grossman and DeJong, 1995). On the other hand, if irrigation rates were above the requirements of the fruit and the balanced tree structure, it would result in extensive shoot growth, which may require additional labor for summer pruning.

Water use efficiency at the orchard level (WUE ${ }_{\text {orchard }}$; fresh weight production/applied irrigation) is the reciprocal of the specific reproductive water use, indicating that $\mathrm{WUE}_{\text {orchard }}$ increases with decreasing specific reproductive use. A decrease in specific reproductive use can be obtained by decreasing annual irrigation rate or increasing crop yield (Eq. 1), and the tree may respond differently to each factor. When specific reproductive use decreases in response to an increase in crop yield (higher crop load) the whole-tree assimilation rate would be increased because of the increased stomatal aperture (Erf and Proctor, 1987; Hansen, 1971). However, the assimilation rate can increase by no more than $\sim 15 \%$ because of increased stomatal conductance (DeJong 1986), whereas in the current study there was a 10-fold 
difference in crop yields between the lowest and highest crop loads. If specific reproductive use decreased because of a reduction in annual irrigation rate, it would result in a deterioration of tree water status, which would be manifested in a reduction in stomatal conductance and assimilation rate. This reduction, in turn, would lead to an increase in $\mathrm{WUE}_{\text {leaf }}$ (assimilation rate/transpiration rate), because the assimilation resistance is always higher than the transpiration resistance due to additional nonstomatal resistance (Jones, 1992); nevertheless, the tree assimilation rate would decrease. Both annual irrigation rate and crop yield affect the rate of the transport of assimilates into the fruit by either changing the supply of assimilates or changing sink capacity. However, severe water stress may attenuate expansive growth by a low turgor potential and a decrease in the rate transport of assimilates in the phloem (Nobel, 1991). It seems, therefore, that the water status in the current study was not low enough to limit expansive growth by a low turgor potential and a decrease in the rate transport of assimilates in the phloem.

The link found in the present study between crop yield and tree annual irrigation rate could potentially be used for planning irrigation and thinning regimes in commercial orchards, in order to achieve the optimum fruit-size distribution. The annual irrigation rate and fruit thinning level can be optimized during the growing season once sufficiently good estimates of crop yield and potential fruit size are available. For example, different specific reproductive water use values would be applied in 1995 and in 1996 , assuming that the commercially optimal fruit diameter is $71 \mathrm{~mm}$; For 1995, when the potential fruit diameter reached 77.1

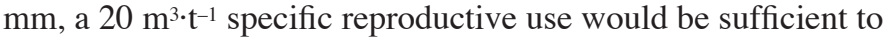
achieve the desired fruit diameter, whereas in 1996, when the potential fruit diameter was $72.2 \mathrm{~mm}$, the specific reproductive use required to reach the same mean diameter would be substantially higher, at $58 \mathrm{~m}^{3} \cdot \mathrm{t}^{-1}$.

The availability of irrigation water would dictate the optimal crop load for each potential fruit size. For example: should water supply be restricted to $550 \mathrm{~mm}$ during the 2 years of the present study, the total reproductive water use for both years would be $230 \mathrm{~mm}$. For an optimal fruit diameter of $71 \mathrm{~mm}$, in 1995 this quantity of water would suffice for a crop yield of more than 110 $\mathrm{t} \cdot \mathrm{ha}^{-1}$ commercially optimal-size fruit, whereas in 1996 thinning should probably be applied, to reduce the crop yield to some 40 $\mathrm{t} \cdot \mathrm{ha}^{-1}$ of similarly sized fruit. It should be noted, however, that reliable technologies for the early-stage assessments of crop yield and of potential fruit size are yet to be developed to enable the benefits from the utilization of the model in commercial orchards to be maximized.

After harvest, when the actual crop yield and fruit size distribution data for each commercial plot are available, the following analysis can be performed. If the data for a specific commercial plot lie on the regression line (Fig. 4), it suggests that the trees were efficient and that whether the irrigation was suboptimal, optimal, or excessive depended on the optimal fruit diameter. If the data for a specific plot lie below the regression line, the trees are considered to be inefficient, which could be attributed to low irrigation efficiency, to an excessive crop load, or to limitation of availability of assimilates attributed to the activities of pests and/or diseases.

\section{Literature Cited}

Assaf, R., I. Levin, and B. Bravdo. 1982. Apple fruit growth as a measure of irrigation control. HortScience 17:59-61.

Austin, P.T., A.J. Hall, P.W. Gandar, I.J. Warrington, T.A. Fulton, and
E.A. Halligan. 1998. A compartment model of the effect of early-season temperatures on potential size and growth of 'Delicious' apple fruit. Ann. Bot. 83:129-143.

Bergh, O. 1985. Effect of the previous crop on cortical cell number of Malus domestica cv. Starking Delicious apple flower primordial, flowers and fruit. South African Tydskr. Plant Ground 2(4):191-196.

Bergh, O. 1990. Effect of temperature during the first 42 days following full bloom on apple fruit growth and size at harvest. South African J. Plant Soil 7(1):11-18.

DeJong, 1986. Fruit effects on photosynthesis in Prunus persica. Physiol. Plant. 66:149-153.

DeJong, T.M. and Y.L. Grossman. 1995. Quantifying sink and source limitations on dry matter partitioning of fruit growth in peach trees. Physiol. Plant. 95:437-443.

Ebel, R.C. 1991. Apple tree and fruit response to drought stress. PhD Diss., Washington State Univ., Pullman.

Erf, J.A. and J.T.A. Proctor. 1987. Changes in apple leaf water status and vegetative growth as influenced by crop load. J. Amer. Soc. Hort. Sci. 114:191-196.

Grossman, Y.L. and T.M. DeJong. 1994. Carbohydrate requirements for dark respiration by peach vegetative organs. Tree Physiol. 14:37-48. Grossman, Y.L. and T.M. DeJong. 1995. Maximum fruit growth potential and seasonal patterns of resource dynamics during peach growth. Ann. Bot. 75:553-560.

Hansen, P. 1971. The effect of fruiting upon transpiration rate and stomatal opening in apple leaves. Physiol. Plant. 25:181-183.

Jones, H.G. 1992. Plants and microclimate: A quantitative approach to environmental plant physiology. Cambridge Univ. Press, Cambridge, U.K.

Lakso, A.N., J.N. Wünche, J.W. Palmer, and L. Corelli Grappadelli. 1999. Measurement and modeling of carbon balance of the apple tree. HortScience 34:1040-1047.

Lenz, F. 1986. Fruit effects on transpiration and dry matter production in apples, p. 101-140. In: A.N. Lakso and F. Lenz (eds.). Regulation of photosynthesis in fruit trees. Symp. Proc., Geneva, N.Y.

Mpelasoka, B.S., M.H. Behboudian, and S.R. Green. 2001. Water use, yield and fruit quality of lysimeter-grown apple trees: responses to deficit irrigation and to crop load. Irr. Sci. 20(3):107-113.

Naor A., I. Klein, I. Doron, Y. Gal, Z. Ben-David, and B. Bravdo. 1997a. Irrigation and crop load interactions in relation to apple yield and fruit size distribution. J. Amer. Soc. Hort. Sci, 122:411-414.

Naor A., I. Klein, I. Doron, Y. Gal, Z. Ben-David, and B. Bravdo. 1997b. The effect of irrigation and crop load on stem water potential and apple fruit size. J. Hort. Sci. 72:765-771.

Naor A., I. Klein, H. Hupert, Y. Grinblat, and M. Peres. 1999. Irrigation and crop load interactions in relation to nectarine yield, fruit size distribution and water potentials. J. Amer. Soc. Hort. Sci. 124:189-193.

Naor A., M. Peres, Y. Greenblat, I. Doron, Y. Gal, and R.A. Stern. 2000. Irrigation and crop load interactions in relation to pear yield and fruitsize distribution. J. Hort. Sci. Biotechnol. 75:555-561.

Naor A., M. Peres, Y. Greenblat, Y. Gal, and R. Ben Arie. 2004. Effects of pre-harvest irrigation regime and crop load on yield, fruit size distribution and fruit quality of field-grown 'Black Amber' Japanese plum. J. Hort. Sci. Biotechnol. 79:281-288.

Nobel, P.S. 1991. Physicochemical and environmental plant physiology. Academic Press, London.

Powell, D.B.B. 1974. Some effects of water stress in the spring on apple trees. J. Hort. Sci. 49:257-272.

Proctor J.T.A., R.L. Watson, and J.J. Landsberg. 1976. The carbon budget of young apple trees. J. Amer. Soc. Hort. Sci. 101:579-582

Taiz, L. and E. Zeiger. 1991. Plant physiology, $1^{\text {st }}$ ed. Benjamin/Cummings Publ., Redwood City, Calif.

Walton E.F. and P.J. Fowke. 1995. Estimation of the annual cost of kiwifruit growth and maintenance. Ann. Bot. 76:617-623.

Warrington I.J., T.A. Fulton, E.A. Halligan, and H.N. de Silva. 1999. Apple fruit growth and maturity are affected by early season temperatures. J. Amer. Soc. Hort. Sci. 124:468-477.

Wibbe M.L., M.M. Blanke, and F. Lenz. 1993. Effect of fruiting on carbon budgets of apple tree canopies. Trees 8:56-60. 